\title{
Glossary of legal terminology
}

Chattels: Items of property other than land.

Chattels real: Leasehold property.

Common law: Body of English law derived from custom and judicial precedent.

Criminal conversation: Often abbreviated to Crim. Con., this was a civil suit against the lover of an adulterous wife, and was an essential prelude to a private divorce bill.

Separation from bed and board: Divorce a mensa et thoro, literally 'divorce from bed and board'. A legal separation granted by church courts on the grounds of adultery and/or cruelty.

Dower: A widow's common law entitlement to a life interest in one-third of her deceased husband's landed property.

Entail: Method of settling property over several generations by deed to ensure it passed intact to future heirs.

Equity: A branch of English law that developed to counter perceived imbalances in common law.

Fee simple: Tenure of land not subject to entail.

Fee tail (or fee entail): Tenure of land which is entailed.

Feme covert: Literally 'a woman covered'. A married women whose legal identity was absorbed, or 'covered', by that of her husband. 
Feme sole: Literally 'a woman alone'. A woman without a husband who therefore retained her own legal identity.

Heir/heiress: A person legally entitled to ownership of a property upon the death of another.

Jointure: A twice-yearly, or quarterly, payment arranged for a woman at the time of her marriage, to take effect upon the death of her husband. This was a life interest and was either charged upon the husband's estate or paid from investments.

Marriage settlement: Private deed drawn up by solicitors at the time of marriage to arrange provision for the wife and children of the marriage.

Pin money: An amount of money arranged for the personal use of a woman during her marriage. This was a life interest and was not payable in arrears.

Separate estate: Either land or investments held in trust for a married woman, for her own use during marriage, not subject to the control of her husband.

Statute law: Legal rules and principles established by statute.

Strict settlement: Type of marriage settlement that arranged the transmission of land to future generations and arranged provision for the wife and children of a marriage.

Trustee: A person holding property on behalf of another as specified in a deed of settlement. 